\title{
CAPTURE OF BOMBARDIER BEETLES BY ANT LION LARVAE'
}

\author{
By Jeffrey Conner and Thomas Eisner \\ Section of Neurobiology and Behavior \\ Cornell University, Ithaca, NY 14853
}

Ant lions (larvae of Myrmeleontidae) are well-known for their unique method of prey capture (Wheeler, 1930). They construct a conical pit in the sand and lie buried at the bottom with only their sickle-shaped mandibles, or head and mandibles, exposed. When an ambulatory arthropod falls into the pit it is seized and pierced by the mandibles and sucked dry. Bombardier beetles, like other Carabidae, are ground foragers and thus may be expected to fall into ant lion pits. However, due to their singularly effective chemical defense, some question remained whether they might be vulnerable to capture by ant lions. Bombardier beetles respond to attack by ejecting an aimed spray of hot $\left(100^{\circ} \mathrm{C}\right)$ repellent quinones from the tip of the abdomen (Eisner, 1958; Aneshansley et al., 1969). The spray is an effective deterrent to a number of insectivores (Eisner, 1958; Eisner and Dean, 1976). Several authors (Turner, 1915; Wheeler, 1930; Lucas and Brockmann, 1981) have observed that ant lions may pull their prey under the sand after grasping it. Lucas and Brockman (1981) suggest that this behavior may protect ant lions from aggressive prey. We here report that ant lions can capture bombardier beetles providing the ant lions have pulled their head beneath the sand by the time the beetles eject their spray.

Our observations were made at the Archbold Biological Station, Lake Placid, Highlands County, Florida, where the ant lions (Myrmeleon crudelis larvae) and bombardier beetles (Brachinus spp.) were taken. Fifteen ant lions were placed in each of three metal boxes $(30 \times 44 \times 18 \mathrm{~cm}$ high) filled with sand to a depth of $8 \mathrm{~cm}$. After the ant lions had constructed pits, bombardier beetles were released individually into the boxes and observed until they slid or walked into a pit and were seized by an ant lion. Two things were noted each time a beetle "fired" after being grasped: (1) whether the

'Paper No. 75 of the series Defense Mechanisms of Arthropods. Paper No. 74 is T. Eisner and S. Camazine, Proc. Nat. Acad. Sci., in press.

Manuscript received by the editor February 25, 1983. 
ant lion's head was above the sand or had already been withdrawn below the surface, and (2) whether the beetle was retained in the ant lion's hold or released. Detection of firings posed no problem since the discharges are accompanied by audible detonations (Eisner, 1958).

A total of 37 captures were witnessed. Five of these involved beetles that were held only momentarily by the larvae and released without being induced to discharge. Another three involved beetles that also failed to discharge, although they were held persistently and were eventually killed and eaten. The remaining 29 encounters resulted in bombardier firings (Table 1). Eighteen of these ended with the beetle escaping: single firings were involved in each case, and the ant lion's head was in all instances exposed when the firing occurred. The beetles were released unharmed promptly after the discharge. In the other 11 encounters in which firings occurred, the ant lions had withdrawn the head beneath the sand by the time the beetles fired, and although there were sometimes repeated discharges, only one beetle secured its freedom. The other 10 were killed and eaten. It is clear that with their heads submerged, the ant lions are much less likely to be repelled by the spray.

One wonders why the larvae did not consistently withdraw into the sand the moment they seized a beetle. We had noted that ant lions commonly pull their victims into the sand, but usually only when the prey is smaller than the predator itself. The beetles that we tested were roughly of the size of the ant lions or even larger, suggesting that the larvae may simply have lacked the strength to pull themselves under while holding such prey. That large insects are indeed commonly "feasted upon on the surface" had previously been noted (MacLachlan, 1865).

In three instances when beetles fired at submerged ant lions, the latter pulled away from the site of discharge by tunneling backward just beneath the sand surface while keeping the beetle in tow. The option of burrowing without loss of prey, in a substrate where burrowing can potentially be quicker than the rate of diffusion of a repellent chemical, could prove helpful to ant lions also in their capture of chemically protected animals other than bombardier beetles. Indeed, a substantial fraction of prey items ordinarily available to ant lion larvae, including ants, carabid and staphylinid beetles, and millipeds, possess dischargeable defensive glands. Interestingly, 
Table 1. Summary of the outcomes of all observed encounters between ant lions and bombardier beetles in which the beetle "fired" defensive secretion. Beetles were more likely to be killed if the ant lion had pulled itself under the sand by the time the beetle fired $\left[p<0.001, \chi^{2}=24.8,1\right.$ d.f., with a continuity correction used (Snedecor and Cochran, 1967)].

\begin{tabular}{cccc}
\hline No. Encounters & Position of Ant Lion & No. Firings/Encounter & Fate of Beetle \\
\hline 18 & head exposed & 1 & all escaped \\
\multirow{2}{*}{11} & head beneath sand & $2.7 \pm 1.7$ & 1 escaped \\
& & $($ range: $1-5)$ & 10 eaten \\
\hline
\end{tabular}

one of the few other predators known to be able to capture bombardier beetles is a tabanid larva that lies in wait while semisubmerged in mud and feeds on the beetles by catching them by a leg and dragging them into the substrate (Nowicki and Eisner, 1983).

\section{ACKNOWLEDGEMENTS}

We thank Dr. Lionel Stange for identifying the ant lions, John D. Crawford and Stephen Nowicki for comments on the manuscript, and the staff of the Archbold Biological Station for hospitality during our stay.

\section{References Cited}

ANeshansley, D. J., T. Eisner, J. M. Widom, ANd B. Widom

1969. Biochemistry at $100^{\circ} \mathrm{C}$ : Explosive secretory discharge of bombardier beetles (Brachinus). Science 165: 61-63.

EISNER, T.

1958. The protective role of the spray mechanism of the bombardier beetle, Brachynus ballistarius Lec. J. Insect Physiol. 2: 215-220.

Eisner, T. AND J. Dean

1976. Ploy and counterploy in predator-prey interactions: orb-weaving spiders versus bombardier beetles. Proc. Nat. Acad. Sci. USA 73: 1365-1367.

LuCAS, J. R. AND H. J. BROCKMANN

1981. Predatory interactions between ants and ant lions (Hymenoptera: Formicidae and Neuroptera: Myrmeleontidae). J. Kans. Ent. Soc. 54: 228-232.

Maclachlan, $R$.

1865. Observations on the habits of the ant-lion (Myrmeleon formicarius). Ent. Mon. Mag. 2: 73-75.

Nowicki, S. AND T. EISNeR

1983. Predatory capture of bombardier beetles by a tabanid fly larva. Psyche, 90: 119-122. 
SNEDECOR, G. W. AND W. G. Cochran

1967. Statistical methods, 6th ed. lowa State University, Ames, lowa.

TURNER, C. $\mathrm{H}$.

1915. Notes on the behavior of the ant-lion with emphasis on the feeding activities and letisimulation. Biol. Bull. 29: 277-307.

WHEELER, D. M.

1930. Demons of the Dust. Norton and Co., New York.

WILSON, D. S.

1974. Prey capture and competition in the ant lion. Biotropica 3: 187-193. 

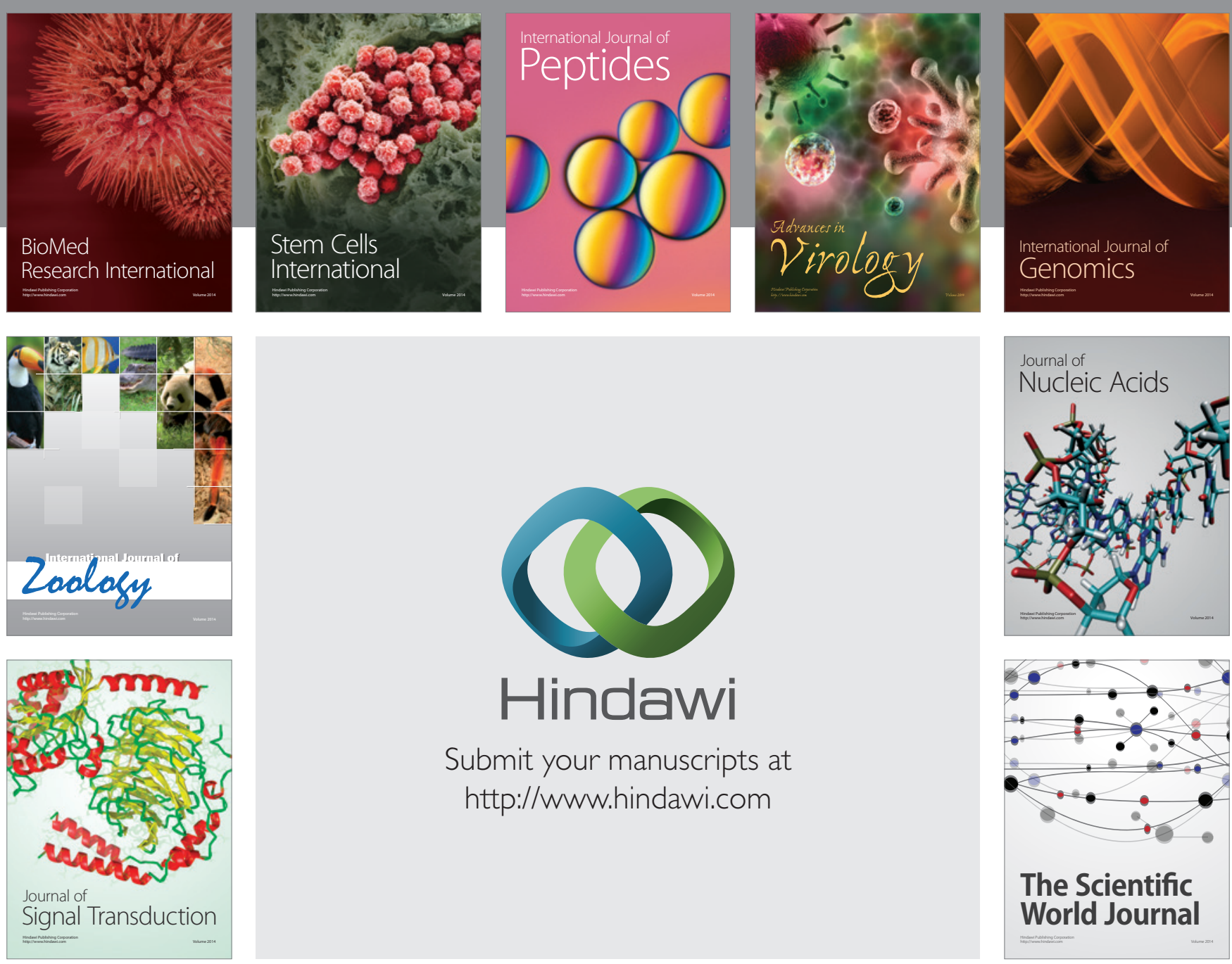

Submit your manuscripts at

http://www.hindawi.com
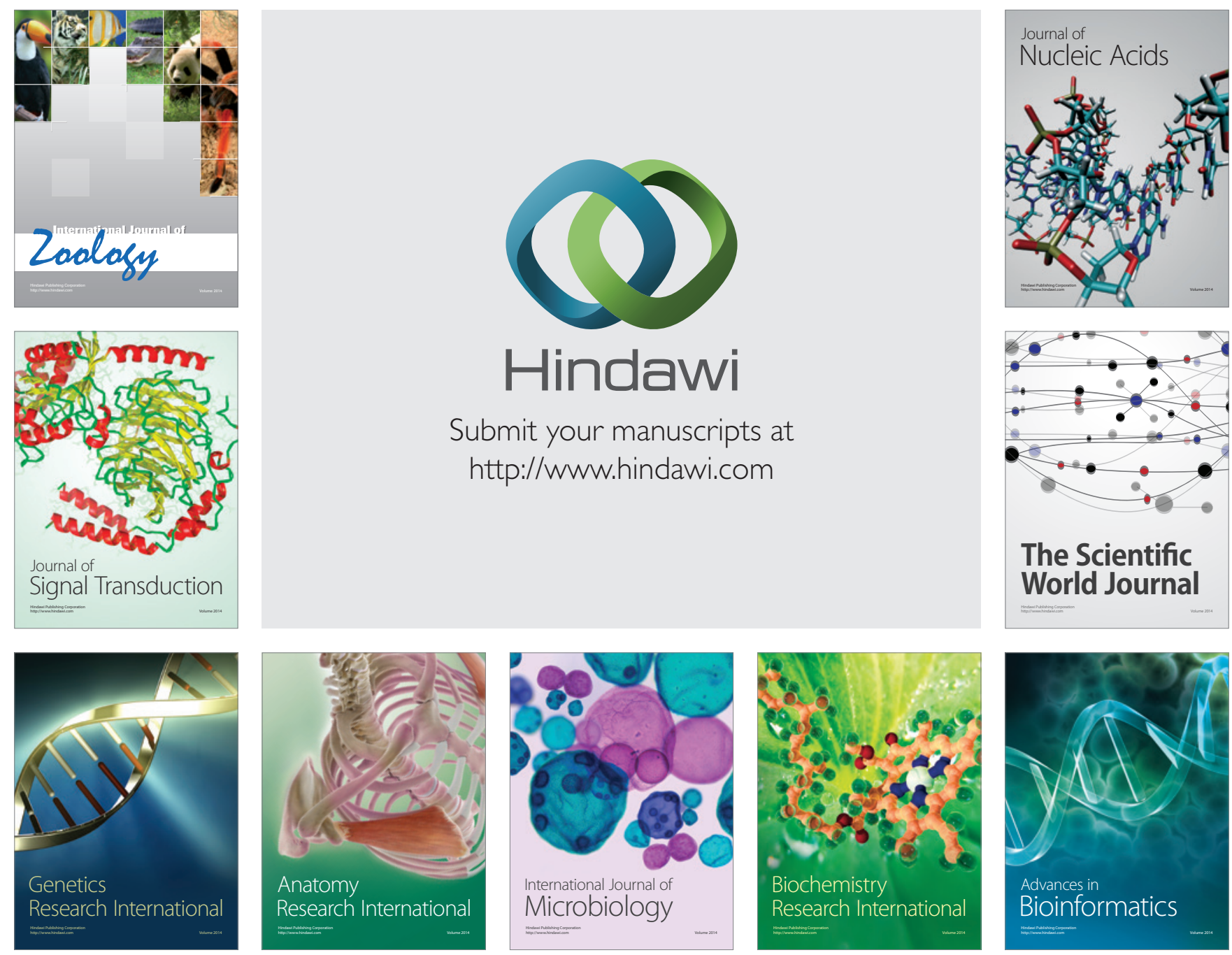

The Scientific World Journal
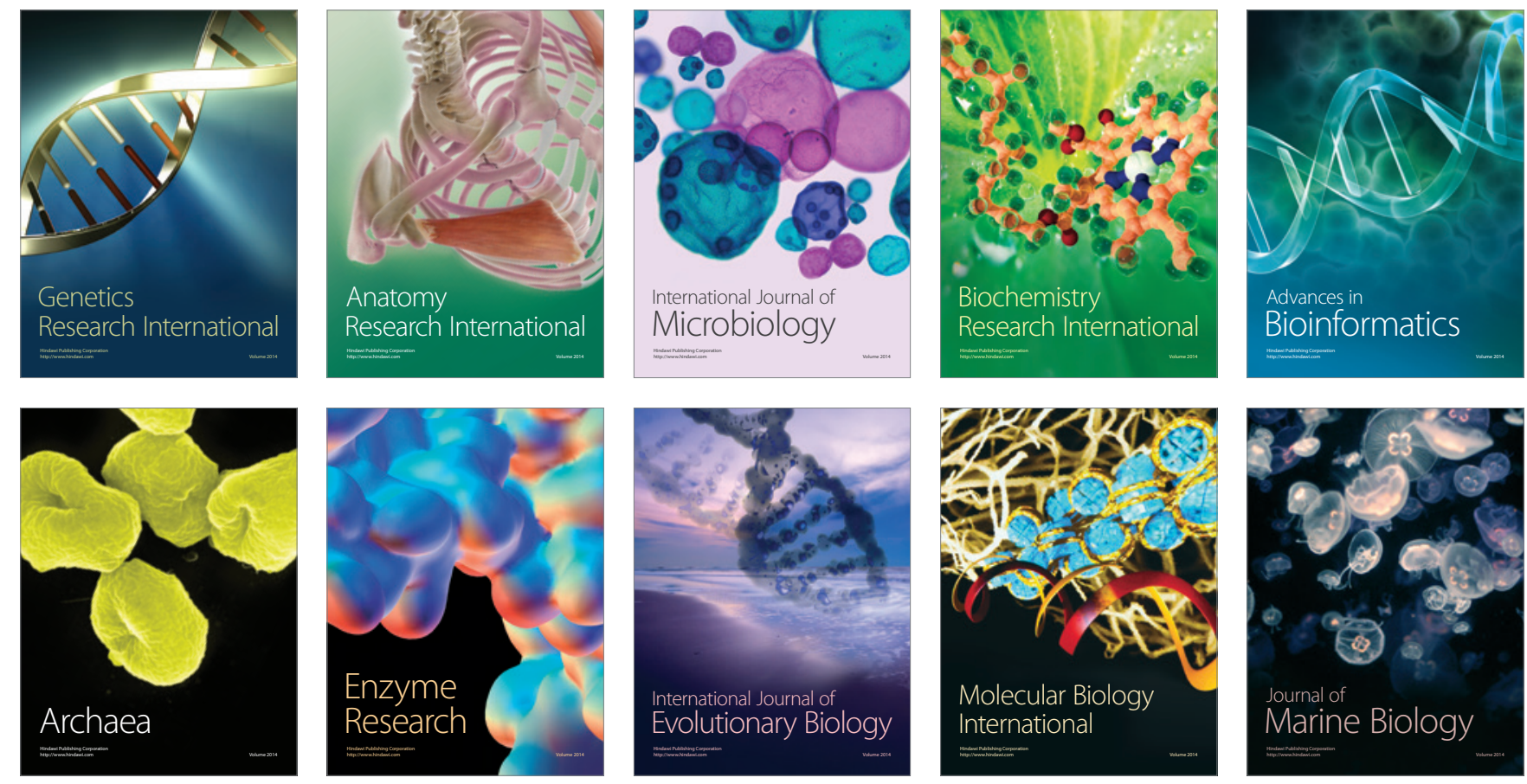